\title{
Did tariffs stifle Spanish agriculture before I936?
}

\author{
JAMES SIMPSON \\ Faculdad de Ciencias Sociales y furidicas, Universidad Carlos III de Madrid, \\ ch Madrid, 28903 Getafe, Madrid, Spain
}

\begin{abstract}
This paper challenges the widely held view that tariff protection was the major factor in explaining the poor performance of Spanish agriculture in the half century prior to the 1936 Civil War. After examining the general level of tariffs, it is argued that these were not sufficient in themselves to explain either the poor diets or weak demand for manufactured goods. Secondly, farmers were slow to switch resources out of cereals, not so much because of the tariffs, but rather because of the limited export opportunities for alternative crops, especially olive oil and wine. Finally, the evidence suggests that those areas which saw a significant increase in the area of cereals were just as likely to see a decline in the agricultural population as those that did not, suggesting that the rural exodus was determined by factors other than the tariff.
\end{abstract}

\section{Introduction}

Agriculture is often blamed for the poor performance of the Spanish economy in the half century or so prior to the I936-9 Civil War. ${ }^{.}$Crop yields were some of Europe's lowest, and output per male labourer was just 39 per cent of that in the United Kingdom in 1930, 44 per cent of that in France, or 38 per cent of that in Germany. ${ }^{2}$ Working capital was minimal, as reflected in the widespread use of the traditional 'roman' scratch plough, the low chemical fertilizer usage, and the low ratios of animal power per hectare. ${ }^{3}$ The cause of agriculture's poor performance is much debated, but perhaps the most frequent explanation is tariff protection, especially that which cereal producers enjoyed. Thus Tortella, after posing the question of why the transition from

' See, for example, Maluquer de Motes I987, p. 75, Nadal I973, pp. 553-67, Tortella I987, pp. 55-9 and I994b, p. 8.

${ }^{2}$ For yields, see Tortella I994a, Table 5 and Simpson 1995a, Table I2.I; for labour productivity, O'Brien and Prados de la Escosura 1992, Table 6. Female agricultural labour is ignored because of measurement difficulties.

3 However, that does not imply there was no change, as illustrated in, for example, Gallego I986. 
'traditional to modern agriculture' was so slow, answers categorically: 'There is a simple answer: protectionism' ${ }^{4}$

In this article I look at three areas where agricultural protection is usually considered as having had a negative effect on economic development. In Section 2, I argue that bread prices were not significantly above those of other more developed European countries where farmers also enjoyed protection. Furthermore, if diets were poor, they were not significantly more so than in other Mediterranean countries. In Section 3 I show that there were few alternatives to cereals given the limited opportunities for expanding wine and olive oil output. Furthermore, the poor pastures found over much of the country made intensive livestock difficult. In the final section I argue that, at least prior to the first decade of the twentieth century, tariffs had only a weak impact in retaining labour in the sector. After this date, farm labour was just as likely to migrate from areas which saw a significant increase in the area of cereals (Castilla-León) as it was to remain (the South). I conclude that the direct contribution of cereal protection in explaining the low productivity of the sector was probably much less than is usually thought by economic historians.

\section{Protection and the Spanish consumer}

... the higher the level of GNP per capita in 1913 or 1929, the lower the nominal protection of agriculture. It seems that the lower-income countries of Eastern and Southern Europe gave heavy protection to both agriculture and manufacturing. ${ }^{5}$

The Spanish economy saw some major changes in the half century or so prior to the Civil War. In particular, Prados de la Escosura has estimated that GDP per head exactly doubled between I859-6I and $1933-35 .{ }^{6}$ This increase in GDP was accompanied by structural changes, with a growth in urbanization and a decline in agricultural employment. But there can be little doubt that Spain was still a poor country in 1936, both in absolute terms, and in comparison with other western European countries. Thus, real GDP per capita in 1929 was only 68 per cent of that in Italy, 40 per cent of that in Great Britain, 46 per cent of that in France and 57 per cent of that in Germany. ${ }^{7}$ In addition, Palafox has identified other indicators - per capita consumption of cotton and energy, numbers of letters or telegrams sent, and literacy, where Spain once more performs noticeably worse than the continent's leading economies. ${ }^{8}$

4 Tortella, I987, pp. 51-2 and I994b, p. 58. In fact Tortella also gives considerable weight to the question of natural resources, see $1994 \mathrm{~b}, \mathrm{pp} .6-\mathrm{ro}$.

5 Emphasis in the original. Lindert 1989, p. 12.

6 This is equivalent to an annual increase of 0.94 per cent. Carreras (1989) gives a more modest growth of 59 per cent, or an annual 0.65 per cent. Prados de la Escosura 1993, Table D2.

7 Prados de la Escosura 1992, p. 36.

${ }^{8}$ Palafox I991, p. 25. For literacy, see also Núnez 1992, ch. 2. 
Table I provides another indicator, this time for a wider selection of countries, and concentrating on an area which most interests us here, namely the relative cost of food in Spain. An hour's work in Spanish cities purchased significantly less than it did in other western Europe countries, with the exception of Italy. Of the other leading European nations, only in France did the low purchasing power of its citizens appear to have approached the level of that in Spain and Italy, although basic foods were relatively cheaper. ${ }^{9}$

Table I. Relative purchasing power of building workers in Europe, 1930.

(The quantity that wages from one hour's labour could buy in major cities, in kilos and litres).

\begin{tabular}{|c|c|c|c|c|c|}
\hline & Bread & Potatoes & Meat & Milk & Sugar \\
\hline Spain (4) & I.79 & 3.93 & 0.27 & $\mathbf{I . 7 9}$ & 0.73 \\
\hline Italy (7) & I. 48 & 3.73 & 0.25 & 2.19 & 0.43 \\
\hline France (4) & 2.34 & 6.04 & 0.29 & 2.53 & I.07 \\
\hline Germany (6) & 3.10 & II .82 & 0.50 & 4.48 & 2.10 \\
\hline Britain (7) & 3.40 & 8.68 & 0.71 & 2.85 & 2.71 \\
\hline Austria (3) & 2.05 & 6.58 & 0.36 & 2.55 & I.23 \\
\hline Ireland (3) & 2.79 & I3.II & 0.64 & 3.28 & 2.43 \\
\hline Low Countries (4) & 2.93 & 13.67 & 0.53 & 4.56 & I. 74 \\
\hline Denmark (I) & $2.4 \mathrm{I}$ & 12.50 & I.I4 & 6.06 & 4.00 \\
\hline Sweden (3) & 2.37 & $\mathrm{I} 5.83$ & 0.89 & 8.64 & $4 \cdot 52$ \\
\hline Estonia (2) & 1.94 & 6.60 & 0.36 & 2.20 & 0.94 \\
\hline Poland (4) & 3.00 & 12.27 & 0.39 & $2.8 \mathrm{I}$ & 0.83 \\
\hline Czechosvkia (3) & 3.25 & $\mathrm{I} 2.2 \mathrm{I}$ & 0.55 & 3.77 & I.30 \\
\hline
\end{tabular}

Note: Building workers wages have been taken as an average between skilled (albañiles) and unskilled (peones) in the leading urban centres, the number of which are given after each country. Bread is from wheat flour, except in the case of Austria, Estonia, Germany and Poland, when rye bread has been used; meat refers to an average of beef, lamb, pork and veal, except when information is lacking, namely Denmark (lamb), Britain (veal), Ireland (pork and veal) and Sweden (pork). Figures in parentheses refer to the number of urban centres. Source: Dirección General de Trabajo, 1931, cuadros lxiii y lxiv, which in turn is based on International Labour Office publications. Information refers to January 1930.

What the Table cannot inform us of course is to what extent the low purchasing power of Spanish urban workers was a reflection of expensive food, and to what extent low wages. But the question of why diets in Spain were so poor in the I930s cannot be simply a question of the level of economic development. Table 2 shows for example that the Irish consumed 23 per cent more calories per individual, 95 per cent more meat, and 228 per

9 In comparison with Spain, French hourly building wages could purchase 3I per cent more for white bread or 54 per cent for potatoes. For an international study of living standards using this source, see Williamson 1995. 


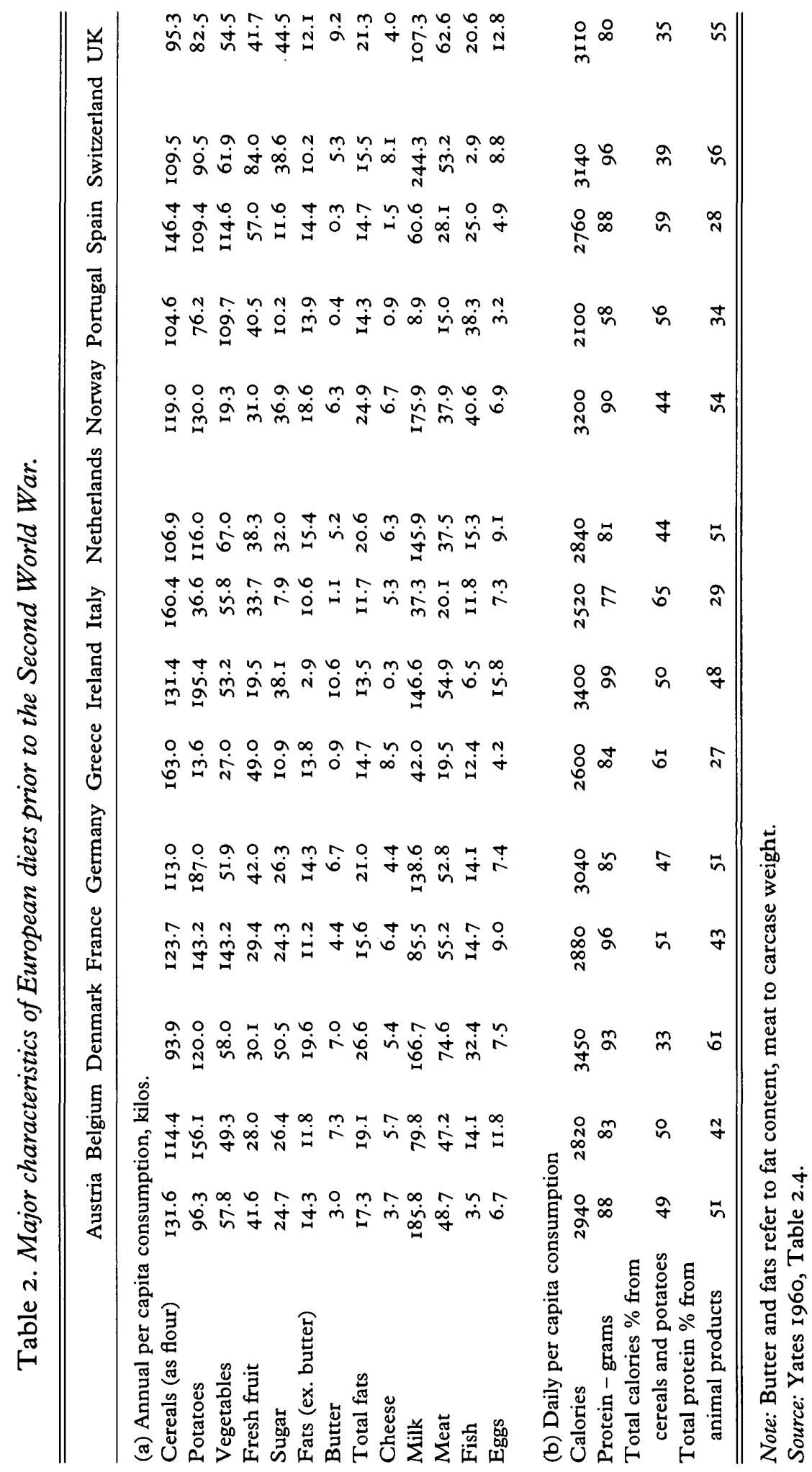


cent more sugar, even though per capita income in the two countries was not very different. However, Table 2 also shows that the low calorie intake, and shortage of animal protein, was a feature of the Mediterranean diet in general, rather than just that of the Spanish. In the rest of this section, I outline first, the major characteristics of cereal protection in Spain and second, whether tariff protection was sufficiently high to explain the differences noted in Tables $I$ and 2.

As Sánchez Albornoz has shown, from I 820 government policy successfully reserved the internal and colonial markets for domestic cereal producers. ${ }^{10}$ However, by the 1880 s the impact of falling production costs in the newly settled temperate countries and the decline in rail and sea freight, threatened to dislodge Spanish wheat farmers from their traditional markets of the periphery (Barcelona, Valencia etc.). Competition was restored by a combination of a depreciating peseta, and an increase in import duties. ${ }^{\text {II }}$ Thus the tariff of 4.54 pesetas/100 kilos was increased to 8 pesetas in December I89I, and again to 10.5 pesetas in February I895. It then tended to fall, but with higher levels becoming operational if the domestic wheat price fell below certain levels. ${ }^{12}$ The first World War saw an extension of government intervention, with attempts to fix maximum and minimum prices. ${ }^{13}$ By the end of the War, Spain had become virtually self sufficient in wheat and the tariff was supplemented from November 192 I by strict import quotas, which were accompanied by maximum and minimum domestic prices. In only three years between 1922 and 1935 did imports rise above 5 per cent of the national harvest (1928, 1929 and 1932), being negligible in the rest. ${ }^{14}$ Despite the dubious success in becoming selfsufficient in wheat and stabilizing consumer prices, the clamour for still greater protection, and reports of distress amongst thousands of wheat farmers during the I920s, questions this as a suitable policy measure, a point examined elsewhere. ${ }^{15}$

If from the late nineteenth century Spain was not alone in protecting its wheat growers, levels were considered exceptionally high, and helped produce some of Europe's highest bread prices. To compare the real level of protection between countries is notoriously difficult, given the variety of methods that protection might take, problems in converting currencies, and

Io Sánchez-Albornoz, 1963. See also Nadal 1985, pp. 93-4.

"See especially Grupo de Estudios de Historia Rural (hereafter GEHR), I980.

I2 See El Progreso Agrícola y Pecuario (EPAPM), abril 1928, no. 1529, pp. 257-60.

${ }^{13}$ The royal decree of August I9I4 allowed, briefly, imported wheat to enter duty free if prices remained above 29 pesetas per 100 kilos. This was reintroduced between March and June, and November of I9I5. Finally, the decree of January I916 established duty free imports until April I92 I. Maximum and minimum prices for wheat were introduced in November 1915.

${ }^{14}$ Montojo Sureda, 1945. See also Pinilla Navarro, I992, pp. 418-20.

is See Simpson 1995a, pp. 222-31. 
the significant dietary variations. Comparing tariff levels alone is not enough (column I, Table 3). ${ }^{16}$ For example, Spain supplemented its tariffs from

Table 3. Indices of wheat protection and self-sufficiency in five European importing nations, 1925-9.

\begin{tabular}{lllr}
\hline \hline Percentages & (I) & (2) & (3) \\
\hline Spain & I9.6 & 96.9 & 19.2 \\
France & 23.0 & 86.2 & 7.8 \\
Germany & 29.0 & 83.9 & 8.0 \\
Italy & 27.0 & 74.0 & 5.6 \\
Gt. Britain & - & 21.2 & 9.2 \\
\hline \hline
\end{tabular}

Notes and Sources:

(1) Duties on imported wheat in 1927, Liepmann (1938).

(2) Level of self-sufficiency in wheat. ${ }^{\star}$ Includes both wheat and rye. The level of wheat self-sufficiency was 6 I. $3 \%$ and rye $99.7 \%$. Source: International Institute of Agriculture, various years.

(3) Income from customs receipts as a percentage of total imports.

Refers to period I922-30. Tena (1992), p. 333.

November 1921 with import quotas for wheat and maize and, therefore, in the words of Liepmann, 'Spain's corn duties ... had only limited practical value for judging her corn-import policy, and the large decreases of her corn imports in post-War periods'. A better reflection of the protection that Spanish farmers enjoyed is in column 2, which shows the country to have been virtually self-sufficient in wheat in comparison to other countries. ${ }^{17}$ If Spanish wheat producers had been competitive in international markets, then domestic self-sufficiency would not be a good indicator of protection. But Spain was not competitive, achieving yields that were little different to those in the United States, but requiring considerably more labour. ${ }^{18}$ Finally, column 3 indicates the generally higher level of protection in Spain across both agriculture and industry compared to other European nations. ${ }^{19}$

Domestic self-sufficiency in wheat was achieved at a cost to the consumer, as domestic prices remained above international ones. Figure I compares the internal wheat price in Spain with the English price, which is taken as the 'world price', and has been converted into pesetas at the current

${ }^{16}$ Liepmann, 1938, p. Ior. For Spanish tariff policy see EPAPM 1928, pp. 257-60 and Montojo Sureda 1945, pp. 15-47.

17 The I.I.A. does not allow a figure for 1909-13 to be calculated as production figures refer to post first World War boundaries, whilst imports to those before the War.

${ }^{18}$ Spain had 8.9 hectares of land per male worker in 1930, against 48.7 hectares in the United States. O'Brien and Prados de la Escosura 1992, Table 5.

${ }^{19}$ For a general study of tariffs in this period, see especially Tena, forthcoming. 
exchange rate. ${ }^{20}$ Whereas between $1870-77$ Spanish wheat prices were cheaper than 'world' prices, this would not be the case for the rest of the period. Only during the first World War, when British prices rose on account of shipping difficulties, did the price difference fall much below 20 per cent.

Other countries, such as France or Germany, also protected their farmers, so Spain was not alone. In the case of France, Lindert has shown that the silver price of wheat grew from being 5 per cent higher than in England during the I870s, to around 26 or 27 per cent by the 1890 s and I900s. In other words, not so very different from the Spanish experience. ${ }^{21}$ Lindert also reminds us that the English Corn Laws kept the domestic price of wheat from around I7IO to I846 significantly above that of other European countries. Indeed, the gap between Britain and other countries in this earlier period appears remarkably similar to that identified in Figure $\mathrm{I}$, between Spain and the 'world price'. ${ }^{22}$ It seems unlikely that higher bread prices caused by tariff protection could make a really significant difference to household budgets in Spain in the period $1891-1936 .{ }^{23}$ However, even if

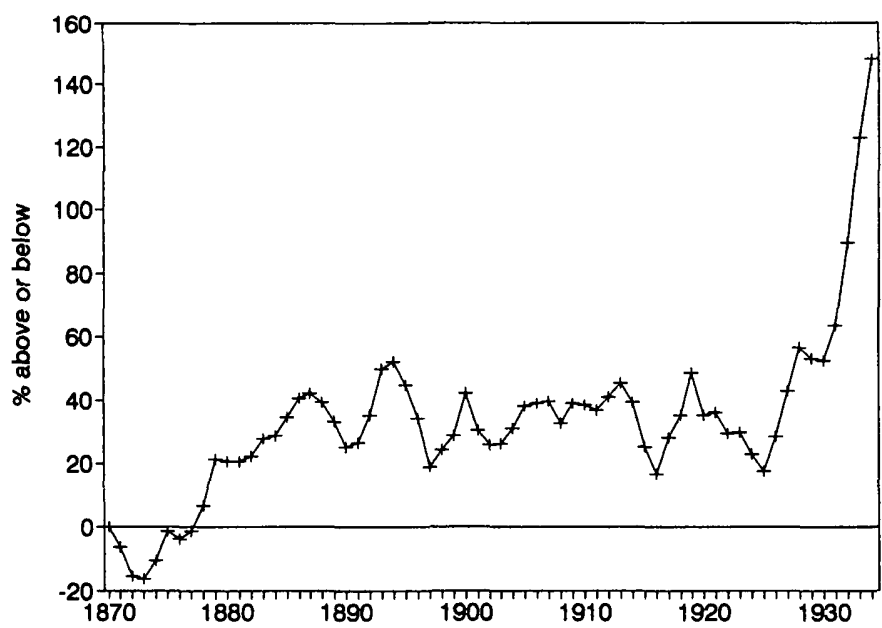

Figure I. Spanish wheat prices as a percentage of 'world' prices.

Note: Figures given as 3 year averages.

Sources: For prices, Mitchell and Deane I962, GEHR I980 and Paris Eguilaz 1943. Exchange rates, Carreras (ed.), 1989, pp. 390-I.

${ }^{20}$ As much of wheat consumed in Britain was imported, there is no need to include freight in the calculation. Unlike GEHR, 1980, who showed the costs (and profits) of shipping from England to Barcelona, our interest here is simply to illustrate the price 'gap' between the two countries. A moving three year price average is used. For a wider comparison of international wheat prices between I880 and I905, see Palafox I99I, cuadro I.3.

${ }^{21}$ Lindert I99I, Table 2.4 .

${ }^{22}$ Ibid. Table 2.4.

${ }^{23}$ Fraile 1993. 
cereal protection in Spain was not significantly above that of its neighbours, the low incomes of the country implied that its relative impact on aggregate demand was greater than in, say, Germany or France. Bread inevitably had a greater weight in the family budget of the lower income countries of the Mediterranean.

\section{Tariffs and the allocation of resources within agriculture}

It follows that the best policy for European countries during the Great Depression was to carry out a shift from crop production to livestock. Countries which were able and far-sighted enough to do this stood a much better chance of overcoming the crisis that those which, in the face of the new trends, persevered with former habits. ${ }^{24}$

Peter Lindert has stressed that governments in recent decades frequently distort their economies by anti-trade policies, as governments 'tend to tax exportable-good agriculture and protect import-competing agriculture' ${ }^{25} \mathrm{In}$ this respect Spain does not appear to have been very different. Spanish producers of oranges, olive oil, olives, wine, grapes, raisins, soft fruits, nuts and early vegetables all suffered to some degree as they had to pay higher prices for wheat, meat, rice, sugar, machinery and consumer goods because of import duties. Whilst it is true that most export crops were themselves protected from imports in the domestic market, it seems unlikely that they would have faced any serious competition without this protection. ${ }^{26}$

It has often been argued that the high concentration of resources in cereals was a major cause of Spanish agriculture's low productivity. Therefore in circa I910, cereals and legumes made up 34.7 per cent of Spain's agricultural final output, but only 23 per cent in France, 22 per cent in Italy, 19 per cent in Germany and 12 per cent in the United Kingdom. ${ }^{27}$ To consider whether tariffs delayed the switch out of cereals and into other crops, I shall consider the problem from two angles, namely the question of lost export opportunities and, as suggested by Tracy's quote above, the delay in transferring resources to livestock farming. I argue that, rather than a misguided tariff policy, it was lack of alternative crops to cereals, in contrast to elsewhere in western Europe, that was the principal obstacle to change.

${ }^{24}$ Tracy 1989 , p. 19.

${ }^{25}$ Lindert I99I, p. 29.

${ }^{26}$ One important exception is the question of substitutes. In this respect wine producers benefited from taxes on imported alcohol, which was often used as a base for the production of other drinks, and olive oil producers from taxes on imports of edible vegetable oils.

${ }^{27}$ O'Brien and Prados de la Escosura 1992, Table 3. Output is valued in national currencies. 
In I935, 87.3 per cent of Spain's wheat production was produced using dry farming techniques, I0.2 per cent using irrigation, and just 2.4 per cent under conditions which would be considered as normal in northern Europe.$^{28}$ In the absence of irrigation, the major alternative crops to cereals in Spain were vines and olives. By the early twentieth century increased domestic demand depended mainly on population growth, with per capita consumption growing by just 8.3 per cent in the case of olive oil, and falling by I. 4 per cent for wine, between $1897-1901$ and I $929-33 .{ }^{29}$ Both crops had important export markets, and it is here that we shall look for lost opportunities because of the protection which cereal farming enjoyed.

The vine was Spain's major export crop throughout the period..$^{30}$ The intensive nature of viticulture made it well suited to the small family farms of the Mediterranean area, and the lack of capital often associated with peasant farming was alleviated in the pre-phylloxera period by the fact that off-farm inputs were minimal. Low entry costs and extensive areas of suitable land for its cultivation were offset only by the bulky nature of the product, and its perishability, as most wines in their natural state frequently became undrinkable within a few months of production. The railways helped lift the geographic restrictions on production, and the addition of alcohol to the wine greatly increased the product's life.

Spanish exports grew rapidly from the early I870s on account of the severely diminished harvests in France, caused by phylloxera (Table 4). The increase in wine prices encouraged a switch away from marginal cereals and pasture, with the area of vines increasing from perhaps $1.5 \mathrm{~m}$. hectares in I 860 to about $2.0 \mathrm{~m}$. in the mid $1880 \mathrm{~s}^{3 \mathrm{I}}{ }^{\mathrm{I}}$ However, the boom was short lived. By the turn of the twentieth century, replanting with disease resistant varieties had allowed French domestic output to recover, and it was the turn for Spanish producers to suffer the widespread destruction by phylloxera. Without the benefit of an abnormal short-fall in a major producing country, Spanish growers needed either to increase market share, or to extend the size of the market. They failed to do either, and the country's share of the world trade in wine slipped from approximately half in the I880s to less than a quarter by $1925-29$.

Spanish exports were severely limited because France, by far the biggest wine market with 62 per cent of world imports in 1925-29, established preferential trade agreements with Algeria. Furthermore, if every producer

${ }^{28}$ Ministerio de Agricultura, 1936, p. 8. Only in the north of the country (Galicia, Asturias, Santander, Guipúzcoa and Vizcaya) was it possible to crop annually without irrigation. Dry farming implied that land was left fallow at least once every two years.

29 Simpson 1989, cuadro 5.

${ }^{30}$ At its peak in $\mathrm{I} 880-4,45$ per cent of all exports were products of the vine (Prados de la Escosura I982, p. 4I).

${ }^{31}$ For the difficulties in measuring the area of vines, see especially Pan-Montojo I994, pp. 384-93 and Simpson 1996, pp. 224-7. 
Table 4. Exports of Spanish bulk wines.

\begin{tabular}{|c|c|c|c|c|c|c|}
\hline & $\begin{array}{l}\text { Total } \\
\text { exports }\end{array}$ & $\begin{array}{l}\text { Exports } \\
\text { to } \\
\text { France }\end{array}$ & $\begin{array}{l}\text { Exports } \\
\text { to other } \\
\text { countries }\end{array}$ & $\begin{array}{l}\% \text { to } \\
\text { France }\end{array}$ & $\begin{array}{l}\text { Spanish } \\
\text { wine } \\
\text { price }\end{array}$ & $\begin{array}{l}\text { Index } \\
\text { Exports } \\
\text { by value }\end{array}$ \\
\hline$I 86 I-65$ & 88.7 & 9.9 & 78.8 & I I & 23.2 & 100 \\
\hline $1866-70$ & III. 5 & 13.0 & 98.5 & I 2 & I9.4 & 105 \\
\hline $1871-75$ & I60.6 & 30.8 & I 29.8 & I9 & 20.2 & 158 \\
\hline I $876-80$ & 302.4 & 180.1 & $\mathrm{r} 22.2$ & 60 & 26.0 & 382 \\
\hline$I 88 I-85$ & 682.7 & 547.9 & $\mathrm{I} 34.8$ & 80 & $35 \cdot 5$ & II 78 \\
\hline I 886-90 & 825.6 & 698.0 & 127.6 & 85 & 26.0 & 1043 \\
\hline $189 I-95$ & 636.4 & 444.5 & I9I.9 & 70 & I6.5 & 510 \\
\hline I896-I900 & 534.6 & 372.0 & 162.6 & 70 & 19.3 & 501 \\
\hline $190 I-05$ & 208.4 & I 43.3 & 65.1 & 69 & 20.7 & 210 \\
\hline I906-10 & I40.I & 42.7 & 97.4 & 30 & I 5.8 & 108 \\
\hline I9II-I5 & 269.9 & I $4 \mathrm{I} .8$ & I28.I & 53 & 27.4 & 359 \\
\hline $1916-20$ & 445.5 & 275.7 & I69.8 & 62 & 30.4 & 658 \\
\hline $192 I-25$ & 278.6 & I66.2 & II2.4 & 60 & 23.2 & 314 \\
\hline
\end{tabular}

Notes: Exports in millions of litres. Wine price refers to San Pere de Ribes (Barcelona). Index of exports obtained by multiplying total exports by wine price; $186 \mathrm{I}-65=100$. Source: Estadistica (s) de Comercio Exterior and Balcells 1980, pp. 375-9.

country restricted imports to protect domestic growers, non-producers also frequently placed high tariffs on wines to protect other domestically produced alcoholic drinks, severely reducing the market for cheap table wines outside France. Even if Spanish growers had managed to improve product quality and establish brand names, which some did, it is unlikely that they would have widened the market significantly. ${ }^{32}$

On the supply side, if producers appear to have responded quickly to an outward movement of the demand curve in the I870s and I880s, they found it less easy to reduce output in periods of depressed demand, as taking vines out of production implied the destruction of costly assets. However, there appear to have been other factors which strictly limited long term profits in viticulture, as wine producers in the pre-phylloxera period experienced conditions not dissimilar to those faced by tropical agricultural producers at this time, namely low entry costs and elastic supplies of land and labour..$^{33}$ Phylloxera raised entry costs by demanding greater inputs of skilled labour and capital, but much of the world's over-production of wine during the first third of the twentieth century stemmed from the extension of vines in regions such as central Spain and Algeria, where the crop's opportunity

${ }^{32}$ In France, for example, the exports of quality wines declined from roughly 60 per cent of production of vins de cru in 1869-77, to 30 per cent in 1913, and Io per cent in 1939.

Warner 1960, p. 85.

${ }^{33}$ For tropical producers, see Lewis 1978 , especially chapter 7. 
costs were low, labour cheap and phylloxera's presence minimal. ${ }^{34}$ Furthermore, as alcohol produced from grapes was more expensive than that produced from other sources, product adulteration remained a major problem, especially when wine prices showed a tendency to rise. Finally, as illustrated in Figure 2, with the brief exception of the period surrounding the first World War, there was no long term price incentive for cereal farmers to switch to viticulture. This is reflected in the fact that the contribution of the viticulture to agricultural output, far from growing, actually declined from I 2 per cent in $189 \mathrm{I}-95$ to 8 per cent in $1929-33.35$

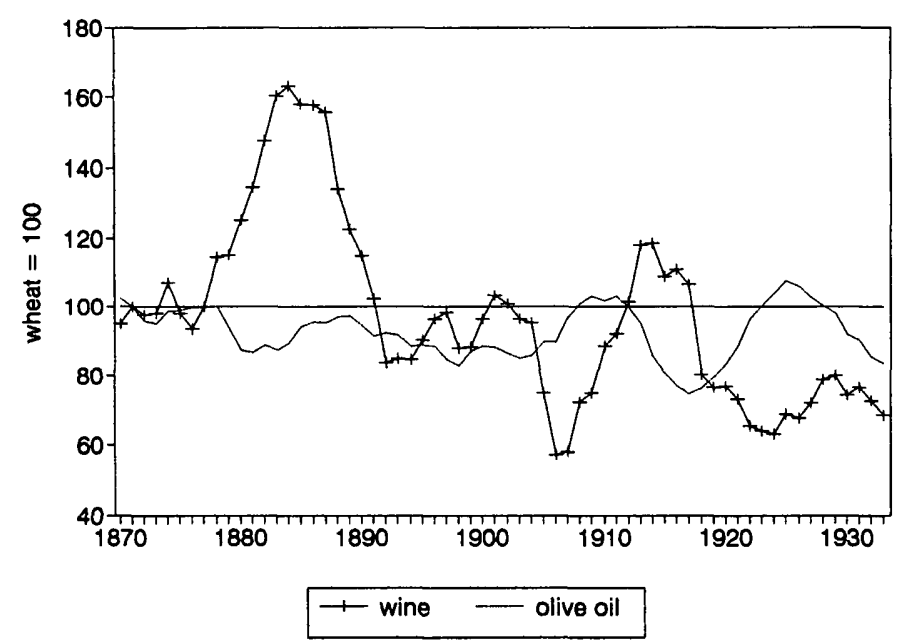

Figure 2. Long mun changes in relative prices of wheat, wine and olive oil.

Sources: Carreras (ed.), I989, pp. II5-I6 and Balcells I980, pp. 376-8. Wheat prices for 1907-12 have been taken as an average of the September price in Valladolid and Barcelona (Anuario estadistico I920, pp. I90-I and I934, pp. 258-9). Olive oil prices for 1908 and 1909 are the average for Barcelona (Anuario estadistico 1920, pp. 190-1).

The olive was another crop of major importance both for the domestic and external market, with about a fifth of total output exported in the decade prior to the Civil War. Between I90I-I2 and I926-35, the area under olives grew by a third, agricultural yields increased by 28 per cent, but

${ }^{34}$ Opportunity costs are difficult to measure, although for La Mancha (Albacete, Ciudad Real, Cuenca and Toledo) wheat yields averaged only 0.6 tons per hectare in 1909-I4 (Torres 1944, pp. 247-72), against a national average of 0.9 in Spain, 0.7 in Algeria, I.I in Italy, I.3 in France and 2.2 in the British Isles (calculated from Malenbaum 1953, pp. 236-9). Lewis notes a figure of $700 \mathrm{lb}$ per acre ( 0.8 tons per hectare) for tropical countries in 1900 (1978, p. 188). In some regions of Algeria and central Spain, phylloxera was still absent in the 1920 .

${ }^{35}$ Simpson 1995b, appendix Id. 
industrial yields in the manufacture of olive oil saw virtually no change. These movements in productivity are deceptive however, for whilst an important part of the increase in agricultural yields appears to have been achieved by simply having a greater proportion of the nation's trees in full production, and by farmers increasing annual variable costs to take advantage of favourable prices (extra ploughings, hoeings, greater care in harvesting, etc.), the most significant change in this sector during the period was without doubt the modernization of the olive mills and presses.

In the nineteenth century, most Spanish olive oil exported was of poor quality, and used for industrial purposes, namely lighting, as a raw material in the manufacture of soap, and as a lubricant for machinery. The growth of other cheaper vegetable substitutes implied that, to retain markets, producers had to improve product quality, switching from the industrial to the edible oil market, which in turn required considerable investment in new plant. From a low of 16.7 thousand tons of olive oil exported in the decade I886-95, exports grew to 74.4 thousand tons in $1926-35$. However, the six major markets for Spanish olive oil between 1865 and 1935, namely Italy, France, Cuba, Argentina, United States and Great Britain, illustrate once again the limitations of the export market for Spanish producers, as five of the six countries were either Mediterranean countries (and therefore producers themselves), or had large Mediterranean immigrant populations. Market size was therefore limited by taste and cultural experiences. ${ }^{36}$

Olive oil processing required a cash investment which could not be easily substituted by labour and which, by allowing economies of scale, gave the larger producer an advantage over the smaller one. This led to a greater concentration of production as small producers sold their fruit to the larger manufacturer. ${ }^{37}$ However, although the technical change in manufacturing increased product quality and opened up new markets, the greater part of the value added was obtained in the growing and harvesting of the crop. Government estimates in I92 I suggest that only Io per cent of the price of olive oil could be attributed to the manufacturing process. ${ }^{38}$ Therefore 90 per cent of the cost of olive oil was based on the use of extensive areas of relatively unfertile soil, and some of Europe's cheapest casual agricultural labour.

As with the viticulture, Spanish olive oil producers found increasing competition from other cheap cost producers in the Mediterranean, and by 1929-33 Greece, Tunisia and Algeria had captured a third of international trade. ${ }^{39}$ However, competition from countries with labour cheaper than Spain's was only part of the problem. The difficulties in mechanizing olive

${ }^{36}$ The sixth country, Britain, was of declining importance from the late nineteenth century as cheaper vegetable oils were used for industrial purposes.

${ }^{37}$ For the example of the company Carbonell in Córdoba, Zambrana 1987, chapter 4.

${ }^{38}$ Dirección General de Agricultura y Montes, 1923.

${ }^{39}$ Zambrana 1987 , p. 296. 
growing, especially the harvest, led to growers facing competition either directly from other, cheaper vegetable oils, or indirectly through the mixing of them with olive oil. This played an important part in depressing prices, and limited the switch of land away from cereals into olives. As a result, if cereals and legumes accounted for 62 per cent of arable land, and 55 per cent of crop output in $189 \mathrm{I}-5$, the area remained unchanged at 62 per cent in I93I, although output fell slightly to 45 per cent..$^{40}$

As suggested by Tracy, a major factor in productivity growth in northern Europe's agriculture from the late nineteenth century was the movement of resources away from the production of bread cereals, where demand tended to be stagnant and producers faced growing international competition, and into livestock products. Thus in Great Britain the area devoted to wheat fell by a half and the number of cattle increased by 30 per cent between 1870 and I9IO. In France, whilst the value of cereals stagnated, the output of meat and dairy produce increased by 48 per cent between $1865-74$ and 1905-14. In Italy, the number of cattle increased by 40 per cent between I 880 and I9IO, and there were significant increases in the numbers of pigs, sheep and goats. ${ }^{4 \mathrm{I}}$ If in Germany there was no fall in the area of wheat and rye, the number of cattle rose by a third between 1873 and $1913 .{ }^{42}$ In Spain, the situation is harder to establish on account of the lack of reliable censuses, and the problem of calculating suitable production coefficients. In general, however, livestock numbers do not appear so very different in 1929 as they were in 1917 or $1865 .{ }^{43}$ By contrast, the area of wheat grew throughout most of the nineteenth century, and increased by 24 per cent and production by 34 per cent between $1905-9$ and 1930-4.

There can be few doubts that this failure to switch resources out of bread grains and into meat and dairy produce was a major cause of the low productivity in the agricultural sector in Spain. That said, it is much more difficult to establish to what extent the failure was the result of tariffs, and to what extent other factors should be blamed.

The question however, is not one of free trade or protection for cereals, as Spanish livestock producers also enjoyed strict controls on imports. Population growth, improvements in per capita incomes, real wages and growing urbanization over the period i $865-1936$ might be expected to have produced an increase in demand for livestock produce. The virtual stagnation in herd size as shown in the censuses of 1865, I9I7 and I933 suggests,

$4^{\circ}$ GEHR I983a, pp. 243-4. Fallow land has been excluded.

${ }^{4 I}$ The number of pigs increased by 28 per cent, sheep by 40 per cent and goats by 36 per cent, Mitchell I992, pp. 347-8.

${ }^{42}$ Statistical Abstract for the United Kingdom, Toutain 1961, Statistisches fahrbuch für das Deutsche Recish, all cited in Tracy, I989 pp. 5I, 76 and I00-I.

${ }^{43}$ Taking the herd size (live weight) to have been 100 in 1865 , it was 98 in 1750,87 in 1917 and 105 in 1929. Garrabou and Sanz (1985) cuadro 20 and GEHR (1978) apéndice. See also Simpson, 1995a, p. I80. 
however, that per capita supply fell. If demand for meat was indeed rising faster than supply, then prices would be expected to be rising against those of bread. Figure 3 shows that this indeed was the case in Madrid from the mid I880s, with growth being especially strong after the first World War. The trend for Paris, although moving in the same direction, was less attractive to livestock producers. In response to these changes in prices, Spanish farmers started to switch resources away from bread grains and into feed. As early as 1926, Flores de Lemus had noted the growing importance of feed grains compared to bread, and suggested that this was the only feasible alternative for cereal farmers, given the stagnation in domestic demand and the impossibility of exporting wheat. ${ }^{44}$ The government also reacted to rising meat prices by allowing annual imports of 283 thousand tons of maize between 1920-33, the equivalent of 44 per cent of the domestic harvest. The value of livestock output increased by 30 per cent between $1909-13$ and $1929-33 .{ }^{45}$

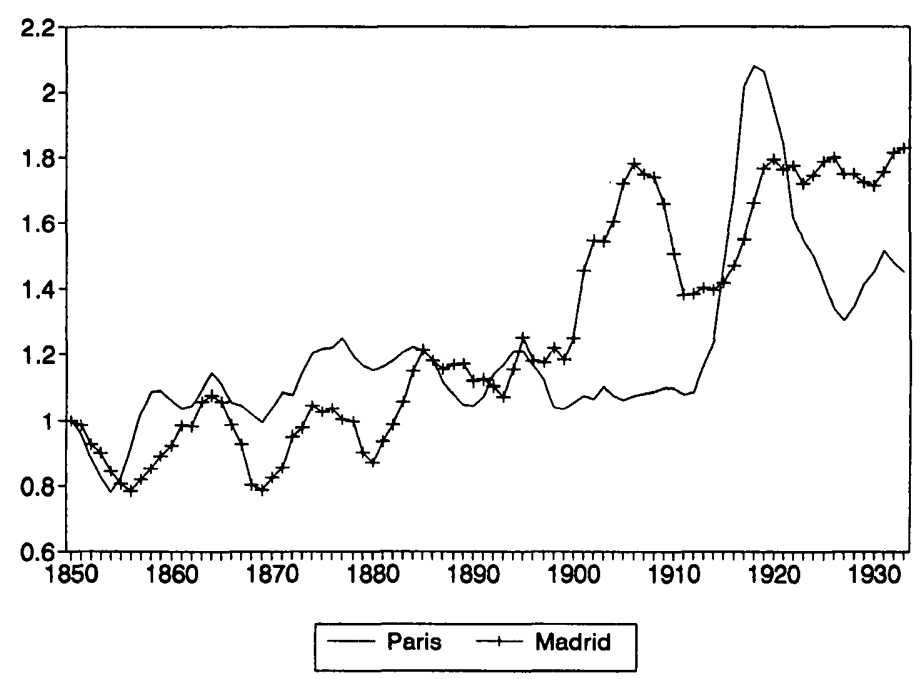

Figure 3. Meat-Bread price ratio in Madrid and Paris, $1850-1930$.

Note: $1848-52=1.005$. Year averages have been used.

Source: Calculated from Singer-Kérel 196I, pp. 462-4 and Reher and Ballesteros 1993, pp. 139-42.

In theory, lower prices for bread, achieved through a more liberal tariff policy, might have released more land for feed grains which could have been diverted towards livestock produce. In reality, such a policy is likely to have had limited results, and for two reasons. First, whereas the arrival of cheap grain allowed a re-orientation of western European agriculture, the possibilities in the Mediterranean countries, and Spain in particular, were much

${ }^{44}$ Flores de Lemus I926. See also Jiménez Blanco 1986 and GEHR I988, p. 6I.

45 Simpson I995b, Table 2. 
less. On the secano, which covers about four fifths of Spain, natural conditions were inappropriate for intensive livestock farming as practiced in Europe prior to the second World War. Second, natural pastures were notoriously poor, and artificial pastures virtually absent. ${ }^{46}$ Until the development of intensive, stall feeding technologies, which could be adapted to Mediterranean type climates, Spain's meat consumption would remain low.

An alternative policy would have permitted free trade in both grains and livestock produce, thereby hastening considerably the rural exodus. If this alternative would have been regarded as far fetched by contemporaries in the pre-Civil War period, evidence presented below suggests that the size of the expected rural exodus would have been smaller than is often supposed.

\section{Tariffs: an obstacle to off-farm migration?}

The belief that tariff policy in Spain slowed the rural exodus is frequently found in the literature. ${ }^{47}$ Likewise, it is argued that protection, in its various forms, is essential to understanding why the area under cereals and legumes increased by 1.47 million hectares, or 18.3 per cent, between $1886-90$ and $1930-5 .{ }^{48}$ While there can be no question that farmers increased output in response to favourable prices, or that the rural exodus would have been faster if the government had not favoured the sector, a closer look at both questions is required.

Between 1887 and 1910, the number of male workers in agriculture increased by 16 per cent, from 4.0 millions to 4.7 millions; by contrast, between I9IO and 1930 the figure fell by 18 per cent, to 3.8 millions. Whereas between 1887 and I9IO agriculture accounted for about two thirds of the active population, the figure in 1930 had fallen to 45 per cent. Recent work by Sánchez Alonso suggests that emigration was weak before about I904, but thereafter increased significantly. However, within a decade, the main attraction for agricultural labour was Spain's rapidly growing cities. ${ }^{49}$ Sánchez Alonso argues that the main explanation to account for the rapid increase in emigration after 1904 was the decline in the real level of protection that cereal farmers enjoyed, on account of the strengthening of the peseta. ${ }^{50}$ However, tariffs were increased across the board in 1906, and

${ }^{46}$ See especially Tortella I994a, and Galassi 1986. In I931 the area of artifical pastures in Spain was 374 thousand hectares, or 2.4 per cent of the total. GEHR I983a.

47 Tortella 1987, p. 52, Prados de la Escosura 1988, p. I02 Sánchez Alonso I995, pp. I $84-5$.

$4^{8}$ GEHR I983b.

49 Between I882 and 1904 Spain had a net emigration of just 185,000 , compared to the 819,000 between 1904 and 1913 . Between 1914 and 1930 there was a net return of I08,000. Sánchez Alonso I995, pp. 45-7 and Table A3.6. See also Tortella I987, p. 52 and Pérez Moreda 1987, p. 36.

so GEHR I980, p. 98 and Sánchez Alonso 1995, pp. 185-6. 
Tena has shown that agriculture was the sector that benefited most. ${ }^{\text {sI }}$ Cereal farmers would also benefit, as we have seen, from direct government price intervention during the interwar period. Yet the years prior to the first World War do appear to be a watershed, as not only does the rural exodus begin to start in earnest, but this also marks the timing of a significant increase in the area of cereals and legumes.

If tariffs encouraged an increase in cereal output, which under conditions found in Spain implied an extension in the area cultivated, ${ }^{52}$ we might expect population to be retained in agriculture in those areas which saw a growth in the area cultivated, and released where there was no increase, or where it was minimal. However, at first glance, Table 5 suggests this was not the case. Between $1886-90$ and $1902-12$ the total area sown with cereals and legumes declined slightly, whereas the labour force grew by 15 per cent. By contrast, between I902-I 2 and I930-5 the area grew by 20 per cent while the labour force fell by the same amount. Nevertheless, a closer look at regional changes in the Table, together with a consideration of wider changes that were taking place, allows us to learn more about the nature of protection, and its impact on Spanish agriculture.

Between $1886-90$ and I902-I2 the rural labour force grew faster in precisely those areas where the area under cereals and legumes declined, namely in the south of the country (La Mancha, eastern Andalucia and Extremadura). ${ }^{53}$ This was caused, at least in part, by the increase in other crops suitable to these regions, namely the olive (especially in eastern Andalucía) and the vine (La Mancha). Nationally, output per male worker stagnated between $189 \mathrm{I}-5$ and 1909-13, caused by a combination of failing to increase cereal output, switching resources more quickly into other higher value crops, or mechanization. ${ }^{54}$ However, it would be difficult to argue, on the basis of Table 5, that protection for cereal farmers was a significant restraint to the rural exodus in this first period.

By contrast, the period between $1902-12$ and 1930-5 does suggest that cereal protection did play some role in determining the speed of the rural exodus. Thus, with the exception of Castilla-León, off-farm migration was fastest in those areas which saw the smallest growth in the area of cereals and legumes. In the south of the country (Andalucía, La Mancha and Extremadura), the area cultivated grew significantly, but the rural population fell only very slightly. However, this poses a paradox, as it implies that in areas of small farms (most notably Castilla-León) tariffs encouraged both an extension in the area sown and a significant fall in farm population; by

si Tena forthcoming.

52 For an explanation of why Spanish cereal farmers increased the area cultivated, as oppose to trying to improve yields, see Simpson I995a, pp. I19-24.

53 Table 5 refers to areas of dry farming, and therefore excludes the northern provinces.

The choice of dates has been determined, at least in part, by the availability of sources.

${ }^{54}$ Output increased by just 12 per cent. Simpson 1995 b, p. 200. 
Table 5. Changes in areas sown of cereals-legumes and rural population.

\begin{tabular}{|c|c|c|c|}
\hline & $\begin{array}{l}\% \text { change in } \\
\text { sown }\end{array}$ & $\begin{array}{l}\% \text { change in } \\
\text { farm population }\end{array}$ & $\begin{array}{l}\% \text { total area } \\
\text { I902-I } 2\end{array}$ \\
\hline \multicolumn{4}{|l|}{ (a) $\mathrm{I} 886 / 90-\mathrm{I} 902 / \mathrm{I} 2$. } \\
\hline Western Andalucía & +13.0 & +4.8 & 8.4 \\
\hline Castilla-León & +2.3 & +16.4 & $23 \cdot 3$ \\
\hline Ebro valley & +1.9 & -0.3 & 10.2 \\
\hline Pais Valenciano & -0.3 & +23.6 & 5.6 \\
\hline Cataluña & -2.3 & +17.4 & 5.9 \\
\hline La Mancha & -12.4 & +20.3 & I4.I \\
\hline Eastern Andalucía & -13.7 & +22.2 & 9.4 \\
\hline Extremadura & -11.3 & $+\mathrm{I} 5.8$ & II. 6 \\
\hline \multirow[t]{2}{*}{ SPAIN } & -1.3 & +15.0 & 88.5 \\
\hline & $\begin{array}{l}\% \text { change in } \\
\text { area sown }\end{array}$ & $\begin{array}{l}\% \text { change in } \\
\text { farm population }\end{array}$ & $\begin{array}{l}\% \text { total area } \\
\text { I930 }\end{array}$ \\
\hline \multicolumn{4}{|l|}{ (b) $1902 / 12-1930 / 5$. } \\
\hline La Mancha & +54.8 & -3.6 & 18.2 \\
\hline Extremadura & +29.1 & -15.3 & 12.5 \\
\hline Castilla-León & +22.0 & $-35 \cdot 3$ & 23.7 \\
\hline Eastern Andalucía & +20.9 & -5.5 & 9.4 \\
\hline Western Andalucía & $+\mathrm{I} 8.6$ & -0.7 & 8.3 \\
\hline Ebro valley & $+\mathrm{I} 8 . \mathrm{I}$ & -I9.I & IO.I \\
\hline Cataluña & $+\mathrm{I} 4 . \mathrm{I}$ & $-.24 \cdot 3$ & 5.6 \\
\hline Pais Valenciano & +8.0 & -28.0 & 5.1 \\
\hline SPAIN & +19.8 & -20.3 & 92.9 \\
\hline
\end{tabular}

Notes: Farm population refers to male labour only.

Regions: Ebro valley (Alava, Huesca, Navarra, Rioja, Teruel and Zaragoza), La Mancha (Albacete, Ciudad Real, Cuenca and Toledo), Extremadura (Badajoz, Cáceres and Salamanca); Western Andalucía (Cádiz, Córdoba, Huelva and Sevilla); Castilla-León (Avila, Burgos, Guadalajara, León, Madrid, Palencia, Segovia, Soria, Valladolid and Zamora); País Valenciano (Alicante, Castellón, Murcia and Valencia), Cataluña (Baleares, Barcelona, Girona, Lleida and Tarragona) and Eastern Andalucía (Almería, Jaén, Granada and Malaga).

The Canary Islands and the north of Spain has been excluded, except for the total area of cereals and legumes.

Sources: GEHR I983b and Censos de población.

contrast, it was in the areas of latifundios (large estates) and day labourers, in the south of the country, where the extension in cultivation was accompanied by a growth in the labour force..$^{55}$ To examine this paradox, we have

ss See especially Bernal, I985, pp. 243-8. 
to consider very briefly the political economy of tariffs, and the wider determinants of migration.

In the face of low cereal prices, the choice of tariffs (or some other system of price support), was just one potential policy option. In other countries, such as Canada or France, agricultural policy was strongly influenced by the interests of the family farmer, as reflected by the dominant role of cooperatives. ${ }^{56}$ In Spain, cooperatives appeared, especially after the first World War, and helped the diffusion of new machinery and artificial fertilizers, but they never seriously influenced government policy. The choice of an agricultural policy based essentially on price intervention reflects the distribution of political power. Protection was the optimal policy choice for the large cereal farmers, and Bernal has argued that the level of protection was deliberately set so that the small family farms in Castilla-León, with generally poorer quality land than in Andalucia, would remain profitable. ${ }^{57}$ However, for the family farm to remain viable, it was necessary to increase the land:labour ratio and this was done, as reflected in Table 5, by both expelling labour and increasing the area cultivated. As I have shown elsewhere, it was in the areas of small farmers where the diffusion of the reapers was fastest before the Civil War. ${ }^{58}$ The example of Castilla-León, which accounted for 26 per cent of the increase in the area cultivated between 1902-12 and 1930-35, and 27 per cent of the decline in the agricultural labour force, suggests that a simple argument relating cereal protection with restricting off-farm migration is incorrect. In the south by contrast, the large estates benefited from cheap labour which frequently made such mechanization unprofitable. Here the over-reliance on systems of price support to maintain farm profitability delayed farm mechanization, which in turn depressed productivity growth. Thus, whilst labour productivity in Castilla-León was 16 per cent greater than in Andalucía in 1909-13, the difference had increased to 52 per cent by $1929-33 .{ }^{59}$ Yet the fact that land:labour ratios in Andalucía were only approximately half those elsewhere, and that wages and living conditions were notoriously poor even with tariffs, suggests that something other than just the price of wheat was determining the rate of off-farm migration. ${ }^{60} \mathrm{~A}$ policy which would have allowed cereal prices to fall to levels such as those in England would no

${ }^{56}$ See, for example, the study by Cleary 1989, for France, and that by Solberg 1987 , for Canada.

57 Bernal 1985, p. 261 .

58 Simpson 1995a, pp. 158-67.

59 In Castilla-León, labour productivity grew by an annual 2.5 per cent beween I9Io and 1930, compared to only I.I per cent in Andalucía. Calculated from Simpson 1995b, Table 7 and Appendix 2.

${ }^{60}$ In 1930, there were 5 hectares of cultivated land per male worker in Andalucia, compared to about ro hectares in the interior of the country. In the Mediterranean region, the figure was 4 hectares, but this would include an important area of high value fruit trees and irrigated land. Simpson 1995a, Table 10.2. 
doubt have reduced living standards even further in Andalucia, but would not have done anything to have increased those other factors, such the supply of information, education, potential access to land, etc., which are often considered as helpful in encouraging rural labour to migrate. Even in the south, tariffs are insufficient to explain the delay in the rural exodus.

\section{Conclusion}

The aim of this paper is to question the importance of tariffs, especially those for cereals, in explaining the backward nature of Spanish agriculture. Despite obvious changes in the economy, not least in the agricultural sector itself, Spain was still a poor country in 1936. However, if diets were poor in comparison to those in northern Europe, this was a characteristic that the country shared with other Mediterranean countries. Yet if tariffs, and other forms of price intervention, pushed prices higher than those on the international market, internal wheat prices in Spain were not so different from those in France or Germany. By contrast, whereas farmers in these two countries reacted to cheap imports both by protection and by switching resources into other commodities, this did not happened to any great extent in Spain. This was due not to the inefficiency of Spanish farmers, but rather the limited market opportunities for alternative crops such as the vine and olive, and the technical difficulties in introducing intensive livestock farming systems in a country which suffered long summer droughts.

In the final section, I argue that tariffs and price intervention cannot explain adequately the speed of the rural exodus. Between I886-90 and 1902-I2, a period which saw the introduction of few labour-saving farm machines, the regions which saw the biggest decline in cereals also experienced the biggest increase in their farm populations. By contrast, the period between 1902-12 and 1930-5 shows a better correlation between changes in the area cropped and the release of labour, suggesting perhaps that tariffs might have acted as a brake on off-farm migration. However, nationally, the active population in agriculture declined rapidly, from about two thirds in I9IO, to 45 per cent in 1930, implying that at best the influence of tariffs must have been weak. More importantly, within Spain itself, the response to price intervention was very distinct. In Castilla-León, the policy appears to have been a stimulus to both off-farm migration and technical change ${ }^{6 \mathrm{r}}$ By contrast, in the south, the size of the labour force declined only slowly, but the area cropped increased.

If tariffs cannot be considered as the major factor in explaining the poor performance of Spanish agriculture prior to the Civil War, what can? Certainly natural resources were not favourable for the type of intensive

${ }^{61}$ In a different context, Clarke 1994, has argued that intervention by the government was crucial in providing the necessary investment climate, so that farmers could take advantages of the new technologies from the r930s, which produced the rapid growth in agricultural productivity in the United States. 
agriculture as increasingly found in northern Europe. But this type of argument has only limited explanatory value, not least because natural resources would not be any different in the 1960's when Spanish agriculture started to modernize rapidly. The poverty and low productivity of the south mentioned above highlights the failure of government policy. However, to blame this on protection, and prescribe less government as being a better alternative, also seems insufficient. Slow productivity growth was just as much a question of the country's poor roads, its inefficient railways, the limited area of irrigation, low investment in elementary schooling or in developing new crops and plant strains, all of which would have required a fundamental overhaul of the country's finances, and an active, not passive role for the state. Whereas it is certainly true that tariffs, whether on agricultural or industrial produce, were easy policy choices, they were also political decisions, and therefore susceptible to the influence of pressure groups. ${ }^{62}$ If Spanish farmers were not encouraged to switch out of cereals because of the higher prices they received because of protection, more serious was the failure of government to provide the lead in developing alternative crops, or in investing in basic infrastructure.

\section{Acknowledgement}

I am grateful to Lluís Argemí, Pedro Fraile, Tim Hatton, Enrique Uopis, Leandro Prados de la Escosura, Antonio Tena, Gabriel Tortella, Francisco Zambrana and to two anonymous referees for helpful comments. The usual disclaimer applies. Financial support was provided by DGICYT PS940005 .

\section{References}

Balcells, A. (1980). El problema agrario en Cataluña. La cuestión Rabassaire. Madrid: Ministerio de Agricultura.

Bernal, A. M. (1985). La llamada crisis finisecular (1872-1919). In García Delgado (ed.), España de la Restauración. Madrid: Siglo XXI.

CARreras, A. (ed.), (1989). Estadistica históricas de España siglos $X I X-X X$.

Barcelona: Fundación Banco Exterior.

ClaRke, S. H. (1994). Regulation and the Revolution in United States Farm Productivity. Cambridge, UK: Cambridge, University Press.

Cleary, M. C. (1989). Peasants, Politicians and Producers: The Organisation of Agriculture in France since 1918. Cambridge, UK: Cambridge University Press. Dirección General de Agricultura y Montes (1923). El aceite de oliva. Madrid.

Dirección General de Trabajo, (193I). Estadistica de salarios y jornadas de trabajo referidas al periodo 1914-1930. Madrid.

EPAPM, El Progreso Agricola y Pecuario (1928). Madrid.

${ }^{62}$ See especially Varela Ortega 1977, and Fraile I99I. 
FloRes de Lemus, A. (1926). Sobre una dirección fundamental de la producción rural española. Reprinted in Moneda y Crédito, I95I, 36, pp. I4I-68.

FRAILE, P. (I99I). Industrialización y grupos de presión. La economía politica de la protección en España 1900-1950. Madrid: Alianza.

FraILE, P. (I993). La economía del proteccionismo. Paper presented at the $V$ Congreso de la Asociación de Historia Económica, San Sebastían.

GALASSI, F. (1986). Reassessing Mediterranean agriculture: retardation and growth in Tuscany, I870-I914. Rivista de storia economica, 3, pp. 9I-I2I.

GALLEGO, D. (1986). Tranformaciones técnicas de la agricultura española en el primer tercio del siglo XX. In R. Garrabou, C. Barciela and I. Jiménez Blanco (eds), Historia agraria de la España contemporánea, 3. El fin de la agricultura tradicional (1900-1960). Barcelona: Editorial Crítica.

Garrabou, R. and SANZ, J. (eds). (1985). Historia agraria de la España contemporánea, 2. Expansión y crisis (I850-1900). Barcelona: Editorial Crítica. GRUPo DE Estudios DE Historia RuRAL (GEHR). (1978). Contribución al análisis histórico de la ganadería española, I865-1929. Agricultura y Sociedad, 8 , pp. I29-82.

GEHR, (I980). Los precios del trigo y la cebada en España, I89I-1907. Madrid: Banco de España.

GEHR, (I983a). Notas sobre la producción agraria española, I89I-I93I. Revista de Historia Económica, I, pp. 185-252.

GEHR, (1983b). Evolución de la superficie cultivada de cereales y leguminosas en España, 1886-1935. Agricultura y Sociedad, 29, pp. 285-325.

GEHR, (1988). La crisis agrícola en Castilla la Vieja y Andalucía: los casos del trigo y el olivar. In R. Garrabou (ed.). La crisis agraria de fines del siglo XIX. Barcelona: Editorial Crítica.

Jiménez Blanco, J. I. (1986). Flores de Lemus y la producción rural de su tiempo. In G. Delgado (ed.) La crisis de la Restauración: España, entre la primera guerra mundial y la II República. Madrid: Siglo XXI.

Lewis, W. A. (1978). Growth and Fluctuations, 1870-1913. London: George Allen \& Unwin.

LiepmanN, H. (1938). Tariff Levels and the Economic Unity of Europe. London: George Allen \& Unwin.

Lindert, P. (1989). Economic Influences on the History of Agricultural Policy. Working Paper, Agricultural History Center, University of California.

Lindert, P. (199I). Historical Patterns of Agricultural Policy. In C. P. Timmer, Agriculture and the State: Growth, Employment, and Poverty in Developing Countries. Ithaca: Cornell University Press.

Malenbaum, W. (1953). The World Wheat Economy, 1885-1939. Cambridge, MA: Harvard University Press.

MAlUQUeR DE Motes, J. (1987). De la crisis colonial a la guerra europea: veinte años de economía española. In J. Nadal, A. Carreras and C. Sudrià (eds), $L a$ economia española en el siglo XX, Una perspectiva histórica. Barcelona: Ariel. Ministerio de Agricultura, (1936). Anuario Estadistico de las Producciones Agricolas, Año 1935. Madrid.

MrtcheLl, B. R. (I992). International Historical Statistics. Cambridge, UK: Cambridge University Press. 
Mitchell, B. R. and Deane, P. (1962). Abstract of British Historical Statistics. Cambridge, UK: Cambridge University Press.

Montojo SuReda, J. (1945). La politica española sobre trigos y harinas (Años 1900-1945). Madrid.

NADAL, J. (1973). The failure of the Industrial Revolution in Spain, I830-1914. In The Fontana Economic History of Europe, 4(2). Glasgow: Fontana/Collins.

Nadal, J. (1985). Un siglo de industrialización en España en el siglo xix. In N. Sánchez-Albornoz (ed.), La modernización económica de España. Madrid: Alianza.

NuÑEz, C. E. (1992). La fuente de la riqueza. Educación y desarrollo económico en la España Contemporánea. Madrid: Alianza.

O'Brien, P. K. and Prados de La Escosura, L. (1992). Agricultural productivity and European industrialization, I890-1980. Economic History Review, 45, 514-36.

Palafox, J. (1991). Atraso económico y democracia. La Segunda República y la economia española, 1892-1936. Barcelona: Editorial Crítica.

PAN-Montojo, J. L. (1994). La Bodega del Mundo. La vid y el vino en España, 1800-1936. Madrid: Alianza.

Parts Eguilaz, H. (1943). El movimiento de precios en España. Madrid: CSIC.

Pérez MoredA, V. (1987). Spain's demographic modernization: I800-1930. In N.

Sánchez-Albornoz (ed.) The Economic Modernization of Spain, 1830-1930. New

York: New York University Press.

Pinilla Navarro, V. (1992). La producción agraria en Aragón (I850-I935).

Revista de Historia Económica, 10, pp. 399-429.

PRAdos De LA Escosura, L. (1982). Comercio exterior y crecimiento en España I826-1913. Madrid: Banco de España.

Prados De la Escosura, L. (1988). De imperio a nación. Crecimiento y atraso económico en España (1780-1930). Madrid: Alianza.

Prados de la Escosura, L. (1992). Crecimiento, atraso y convergencia en España e Italia: introducción. In L. Prados de la Escosura and V. Zamagni (eds), El desarrollo económico en la Europa del sur. Madrid: Alianza, pp. 27-55.

Prados de la Escosura, L. (I993). Spain's Gross Domestic Product, I850-I990: A New Series. Documento de Trabajo, Ministerio de Economia y Hacienda.

Reher, D. y Ballesteros, E. (1993). Precios y salarios en Castilla la Nueva: La construcción de un índice de salarios reales, I501-1991. Revista de Historia Económica, II, pp. IOI-I5I.

SÁNChEZ-Albornoz, N. (1963). Las crisis de subsistencias de España en el siglo XIX. Rosario, Argentina: Instituto de Investigaciones Históricas.

SÁnchez Alonso, B. (1995). Las causas de la emigración española I880-1930.

Madrid: Alianza Universidad.

Simpson, J. (1989). La producción agraria y el consumo español en el siglo xix.

Revista de Historia Económica, 7, pp. 355-88.

Simpson, J. (1995a). Spanish Agriculture: The Long Siesta, 1765-1965. Cambridge,

UK: Cambridge University Press.

Simpson, J. (1995b). Spanish agricultural production and productivity I890-1936. In P. Martin-Acena and J. Simpson (eds), The Economic Development of Spain since 1870. Aldershot, UK: Edward Elgar.

Simpson, J. (I996). La oferta y la demanda de vinos españoles en el siglo XIX. In 
A. Gómez Mendoza, Economía y sociedad en la España moderna y contemporánea. Madrid: Editorial Síntesis.

Singer-Kérel, J. (I96I). Le cout de la vie à Paris de 1840 à I954 (Vol. 3 of Recherches sur l'économie française of the Service d'étude de l'activité économique de la FNSP). Paris: Armand Colin.

Solberg, C. E. (1987). The Prairies and the Pampas. Agricultural Policy in Canada and Argentina. Stanford, CA: Stanford University Press.

TENA, A. (I992). Protección y competitividad en España e Italia, I890-I960. In L. Prados de la Escosura and V. Zamagni (eds), El desarrollo económico en la Europa del sur. Madrid: Alianza.

TENA, A. (forthcoming). La protección nominal en España 1870-1930: nuevos indicadores e interpretaciones. Madrid: Banco de España.

ToRres, M. DE (1944). El problema triguero y otras cuestiones fundamentales de la Agricultura española. Madrid: CSIC.

Tortella, G. (1987). Agriculture: a slow-moving sector, I830-I935. In N.

Sánchez-Albornoz, The Economic Modernization of Spain, 1830-1930. New York: New York University Press.

Tortella, G. (I994a). Patterns of economic retardation and recovery in southwestern Europe in the nineteenth and twentieth centuries. Economic History

Review, 47, pp. I-24.

Tortella, G. (I994b). El desarrollo de la España contemporánea. Historia económica de los siglos XIX y XX. Madrid: Alianza.

ToutaIn, J. C. (196I). Le produit d'l'agriculture française de I700 à 1958. Cahiers de l'ISEA, $A F_{4}$.

TrACY, M. (1989). Government and Agriculture in Western Europe 1880-1988.

London: Harvester Wheatsheaf.

Varela Ortega, J. (I977). Los amigos politicos. Partidos, elecciones y caciquismo en la Restauración (I875-1900). Madrid: Alianza.

WARNER, C. K. (I960). The Winegrowers of France and Government since 1875. New York: Columbia University Press.

Williamson, J. G. (I995). The evolution of global labor markets since 1830 : background evidence and hypotheses. Explorations in Economic History, 32, pp. I4I-96.

Yates, P. L. (1960). Food, Land and Manpower in Western Europe. London: Macmillan.

Zambrana, J. F. (1987). Crisis y modernización del olivar español, 1870-1930. Madrid: Ministerio de Agricultura. 